INDEPENDENT JOURNAL OF MANAGEMENT \& PRODUCTION (IJM\&P)

http://www.ijmp.jor.br

v. 11, n. 7, November - December 2020

ISSN: 2236-269X

DOI: 10.14807/ijmp.v11i7.1239

\title{
EVALUATION THE EFFECTS OF BRAND PASSION ON COMMITMENT TO BRAND THROUGH THE ADJUSTING ROLE OF ETHICS OF BRAND
}

\author{
Mohammad Bagher Arayesh \\ Islamic Azad University, Iran \\ E-mail: hadi.watershed@gmail.com \\ Ali Touhidi Moghaddam \\ Islamic Azad University, Iran \\ E-mail: a.tohidimoghaddam@yahoo.com \\ Shahram Sultani \\ Islamic Azad University, Iran \\ E-mail: me.norouzi1988@gmail.com
}

Submission: 1/7/2020

Accept: 1/21/2020

\section{ABSTRACT}

Regarding the existence of different brands in the various fields of consumer products, customers' commitment to the brand is an important factor in the success of the product of the brand. The present research studies the effects of brand passion on commitment to the brand with regard to the adjusting role of ethics of the brand. Regarding the goal of the study, research methodology applied is practical, and it is conducted as a survey. The research tool comprised three standard questionnaires; for measuring brand passion a 14-question questionnaire (Vallerand et al., 2003) was used, for measuring commitment, a 16-question questionnaire was employed (Shukla et al., 2016), and finally, for the ethics of the brand, a 6-question questionnaire was applied (Brunk, 2012). The statistical community of the study comprised all the consumers of the brands of the sanitary cleaners and detergents. The 384 subjects were selected through a random sampling method. The data thus gathered was analyzed by the software SMART-PLS. And the results showed that brand passion had a positive effect on brand commitment while the variable of the brand ethics had an adjusting role in such effect. Therefore, it is recommended that the managers of the brands of sanitary cleaners and detergents pay special attention to the ethical aspects of the brands so as to increase the commitment of the customers to their brands. 
DOI: 10.14807/ijmp.v11i7.1239

Keywords: brand passion, brand commitment, ethics of brand, sanitary cleaning products

\section{INTRODUCTION}

Nowadays, the highly competitive markets of goods and proliferation of various products and services under different commercial brands have given the consumers ample scope for choice. The great flourishing of brands in the markets, however, has brought about a challenge which is the focus of attention for many businessmen; that is, the customers have many choices to make from the brands before they may become committed to a certain one (SHUKLA; BANERJEE; SINGH, 2016).

Customer commitment is usually defined as an important part of a successful relationship, because it causes a series of mediating relations which, in turn, result in a longterm relationship among the parties involved in the circulation of a service (ALKILANI et al., 2012). In marketing science, brand commitment is the lasting willingness of customers for keeping their relationships with the brand (ERCIS, 2012).

This also means that committed customers usually like to keep a close emotional relationship with a brand that has given them a lasting delightful feeling (KEH, 2007). Also, previous studies also show that different factors such as attitude toward brand, the character of brand, the identity of brand, and love for brand have effects on commitment to brand (JOHNSON; MORGESON; HEKMAN, 2012; PARK; EISINGERICH; PARK, 2013). The present research studies the effects of brand passion on brand commitment with regard to the ethics of the brand as an adjusting variable.

Attraction to a brand is a very positive emotional feeling toward a certain brand which leads to an emotional attachment and affects the behavior of the customers, and as brand commitment also enhances the emotional relationship between the brand and its customers, it is most probable that brand passion become connected to brand commitment (KEH, 2007; ALBERT et al., 2010). It also is a fact that the felt ethics is the true feelings that consumers have toward the honesty, accountability and liability of a brand for all the parties involved (SINGH; IGLESIAS; BATISTA-FOGUET, 2012).

While the relationship between the brand passion and commitment to brand is amply documented and realized, there are no such certain facts about the effects of perceived ethicality and brand commitment (BRUNK, 2012). This being said, the perceived ethicality of the brand is an important factor involved in consumers' decision-making because it affects their 
DOI: 10.14807/ijmp.v11i7.1239

evaluation and selection of the commercial brands (PALIHAWADANA; OGHAZI; LIU, 2016).

Therefore, as the positive feelings of the customers for a brand concerns the attractions of it, the role of the ethics of brand is highly important because it can add to this attraction from many different aspects and gives the brand good potential for change in the effects of brand passion on its commitment feeling (DAS et al. , 2018). Although some studies show that the factor of brand passion and the importance of ethical aspects involved in the development of a brand can attract more attention to it through a certain process (DAS et al., 2018; PALIHAWADANA; OGHAZI; LIU, 2016), various considerations show that no studies have ever accounted for the contribution of ethical aspects in enhancing or decreasing the effects of brand passion on brand commitment.

The present study, therefore, has intended to cover this shortcoming. Thus, the major question to be posed is what effects do the brand attraction and the adjusting role of ethics have on commitment to brand?

\section{THEORETICAL BASES OF THE STUDY}

\subsection{Brand Commitment}

Commitment is simply defined as consumers' positive feelings toward a certain brand (LASSAR et al., 1995). In fact, the brand is also a commitment to the consumers. This means that when costumers buy a product or service from you, they come under the cover of your brand. Thus, the commitment of brand might well have a more lasting and greater effect on the customers than the product itself. Brand commitment also involves the feelings that customers have when they are actually using your products or services (DAS et al., 2018).

This also comprises a stable feeling or attitude that people have toward a certain company, or commercial name and brand. The degree to which customers, as the members of an organization, are mentally and emotionally attached to the name and products of a company, and through a constant tendency for keeping their membership in it, seek to fortifying their relationships with it can also be considered as commitment to brand (MOORMAN et al., 1992).

Some scholars define customers' commitment to a brand as their constant desire for keeping a valuable relationship with the name and status of a trade organization. This can affect the outcomes of the transactions directly and indirectly through commitment (MORGAN; HUNT, 1994). As commitment to brand causes a psychological attachment in the customers to the organization or company, the businessmen should try to know and realize the emotional 
DOI: 10.14807/ijmp.v11i7.1239

needs of their customers, increase the power of their brands and use every possible chance for innovation in this regard (MOORMAN et al.,1992).

Also, it is important to know that commitment comprises the two structures of commitment to continuation and emotional commitment, the former of which is defined as the slight feelings of a person to a brand, while the latter one is more intense and emotional than the commitment to continuation, and comes about through the mutual and personal relationship and participation of a customer in a company. This can lead to the highest degree of trust and commitment (GUSTAFFSSON et al., 2006).

\subsection{Brand Passion}

Although consumers naturally face and have interaction with highly large number of products, they have emotional attachment to only a limited number of them. Many scholars have studied the reasons why consumers of products and services form their interest or lack of it toward various brands in the recent years. However, more recent studies have discovered ever higher degrees of emotional involvement with brands or interest for them. The highest degree of such relationship is brand passion (RAUSCHNABEL; AHUVIA, 2014).

Brand passion is a motivational force which is considered in many fields of consuming and the expression of strong feelings of the consumers (HEINRICH et al., 2009). It is a new concept and structure in marketing. Brand passion is defined as a very positive emotional state in relation to a brand which results in an emotional attachment and affects the behavioral factors (ALBERT et al., 2010).

It consists of two major features, namely, the presence of the brand in the mind of the consumer and the ideal of the brand (ALBERT et al., 2013). It also is suggested that passion can have two main parameters: obsessive brand attraction and coordinatedbrand passion (VALLERAND et al., 2003). In many cases, a coordinatedpassion for a brand provides an internal motivation which enables the customers to keep their relationship along with the other aspects of their life styles (ALBERT et al., 2013; THOMSON; MACINNIS; PARK, 2005).

Yet, there are times when customers, because of their lack of passion for a brand, become uncertain about their feelings and face an obsessive concern for a brand and, therefore, turn committed to that brand. This is how the attractions of a brand may lead to commitment to it (RAUSCHNABEL; AHUVIA, 2014). And finally, it can be said that brand passion can cause very strong feelings in the customers which give meaning to their relationship with it and 
DOI: 10.14807/ijmp.v11i7.1239

forces the customers into investing their assets on it and even make a brand similar to the products they like and keep a lasting relationship with it (SWIMBERGHE et al., 2014).

\subsection{Brand Ethics}

As we said above, the perceived ethicality of a brand can be defined as the honesty, accountability and liability of brand that customers perceive it has toward all the parties involved (SINGH; IGLESIAS; BATISTA-FOGUET, 2012). As a solution in the marketplace, brand ethics has recently considered a large range of political, moral and social issues. By demonstrating its ethical beliefs, the company behind a brand presents a simple solution for the customers who care for and believe in morality: buying brands that represent a value system they believe in and avoiding buying those which discord with their moral beliefs (EGAN et al., 2014).

Not caring for ethics will certainly harm a business; therefore, the ethicality of business perceived by customers can enhance their satisfaction, loyalty and even, the special value of the brand (CASTALDO et al., 2005). It also is interesting to note that companies have begun to use the brand ethics as a strategic measure for determining, distinguishing and preserving their brands in competitive markets (BRUNK, 2012). Perceiving the ethical brand is based on the ethical theory prescribed by the Moral Philosophy (BARNETT; CAFARO;NEWHOLM, 2005). Two major principles underlie this philosophy: 1- Deontology (responsibility), 2Teleology (result-oriented). Based on such theory, a person may measure the legal and ethical standards of their behavior and evaluate the brand they want by the two options of "right" or “wrong” (BRUNK, 2012).

Therefore, the brand ethics both with regard to moral philosophy and teleology considers the perceptions that ethics has of brand. The responsibility-oriented approach (moral philosophy) evaluates the moral qualities of brand such as justice, honesty, transparency and other moral norms because ethical brands are also considered as the reflectors such human values as compassion, trust and care for the shareholders (GROHMANN; BODUR, 2015). Based on the result-oriented approach (Teleology), the focus is on the positive outcomes of the actions that a company undertakes for the customers such social responsibility, social participation and humanitarian acts (BRUNK, 2012).

\section{RESEARCH DESIGN \& METHODS}

With regard to its aims, the present study is a practical one and regarding its conducting method, it is a survey. 


\subsection{The Model of the Study}

Based on what has been related in the theoretical bases of the study, the following model and assumptions can be devised for the research:

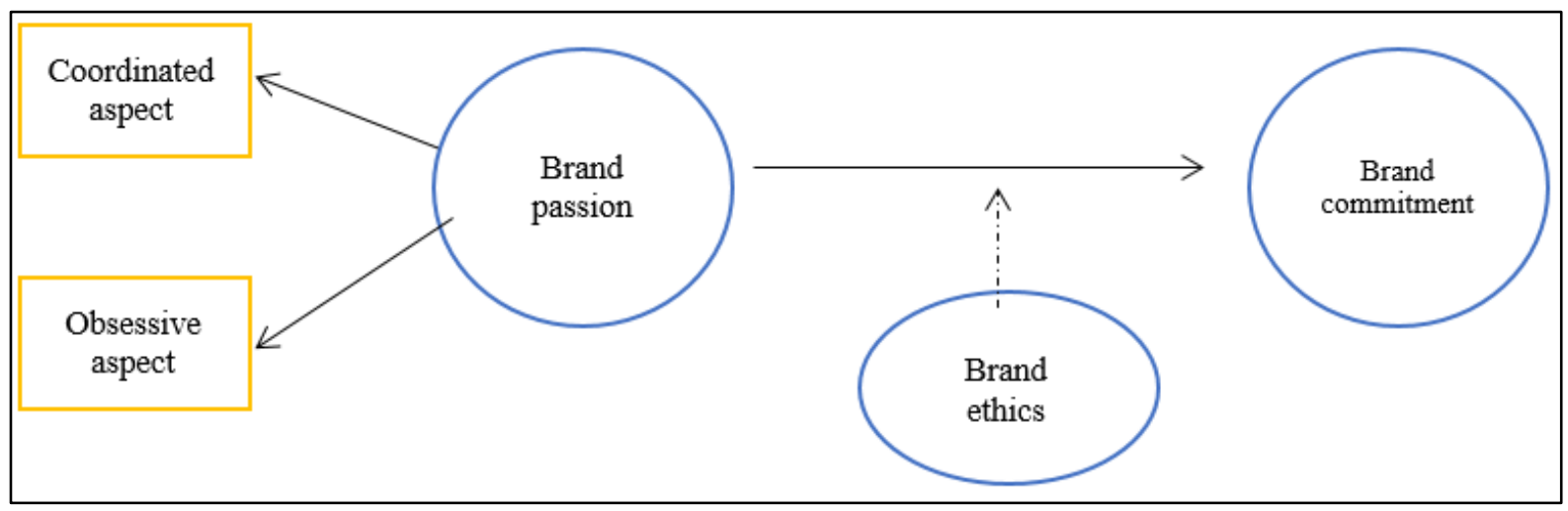

Figure 1: following model and assumptions

\subsection{The first hypothesis of the study:}

Through the adjusting role of ethics, brand passion can affect brand commitment.

\subsection{The second hypothesis of the study:}

Without the adjusting role of ethics, brand passion can affect brand commitment.

\subsection{The statistical community and samples}

The statistical community of the study comprised all the consumers of sanitary cleaners and detergents whose true number is not known. Therefore, a sample of 384 persons was selected based on the Morgan- Krejcie table. The sample method was simple random one based on which the researchers went to chain stores and asked the people who bought sanitary cleaners and detergents to fill out the questionnaires. Finally, 391 questionnaires were filled out.

\subsection{The measurement tools of the study}

The research tool comprised three standard questionnaires; for measuring brand passion a 14-question questionnaire (VALLERAND et al., 2003), for measuring commitment, a 16question questionnaire was employed (SHUKLA et al., 2016), and finally, for the ethics of the brand, a 6-question questionnaire was used (BRUNK, 2012).

\section{VALIDITY AND RELIABILITY OF THE TOOLS}


DOI: 10.14807/ijmp.v11i7.1239

Although the standard questionnaires of the study had been used before this and their reliability and validity approved of, we checked those qualities again. First for measuring the validity of the tools, we used the formal validity was conducted through consulting the viewpoints of the professors of the field. For the reliability of them, however, the Cronbach alpha coefficient was used so that first 30 questionnaires were handed out to the buyers of sanitary cleaners and after collecting them, it was found that the alpha coefficients have all been more than 0.7 , thus approving of the reliability of the questionnaires. The following table shows the result for the reliability of the tolls after applying the Cronbach alpha test.

Table 1: reliability status of the variables

\begin{tabular}{|c|c|c|}
\hline Reliability status & Cronbach alpha values & variables \\
\hline affirmed & 0.78 & Brand passion \\
\hline affirmed & 0.81 & Brand passion \\
\hline affirmed & 0.74 & Brand ethics \\
\hline
\end{tabular}

\section{1. $\quad$ Results \& Analysis}

The first hypothesis: Through the adjusting role of ethics, brand passion can affect brand commitment. For studying the hypothesis of the research, we shall first consider the adjusting role of ethics in brand passion's effect on brand commitment. All the statistical tests were done by using Smart-PLS software. As we can see from the table 2 below, the brand ethics comprising the two aspects of obsessive passion and coordinated passion for the brand, has an adjusting role, because on the effects of passion on commitment to brand, we have $F=14.137$ and also sig=0.000. Therefore, we can conclude that brand ethics has an adjusting role with regard to brand passion. In other words, the brand ethics can adjust the effects of brand passion on brand commitment.

Table 2: results from the hierarchal Regression test

\begin{tabular}{|c|c|c|c|c|c|c|c|}
\hline \multirow{2}{*}{$\mathbf{R}$} & \multirow{2}{*}{ R square } & \multirow{2}{*}{$\begin{array}{c}\text { Adjusted } \\
\text { R square }\end{array}$} & \multicolumn{5}{|c|}{ Change statistics } \\
\cline { 3 - 8 } & & & $\begin{array}{c}\text { R square } \\
\text { change }\end{array}$ & F change & df 1 & df 2 & $\begin{array}{c}\text { Sig F } \\
\text { change }\end{array}$ \\
\hline 0.6901 & 0.477 & 0.471 & 0.019 & 14.137 & 1 & 390 & 0.0000 \\
\hline $1 . \quad$ Brand passion & \multicolumn{7}{|l|}{} \\
\hline
\end{tabular}

Now after finding out about the adjusting role of brand ethics, we shall determine the degree to which this variable is powerful in adjusting the effects of brand passion on brand commitment. The figure below shows the intensity and power of the brand ethics in adjusting the relationship between the variables of the study. It is indicated that the relationship between adjusting role is significant in such relationship. And as the value of $t$ is greater than 1.96 , the 
DOI: 10.14807/ijmp.v11i7.1239

intensity of the adjusting variable of ethics is also significant. Thus, the first hypothesis of the study is approved of.

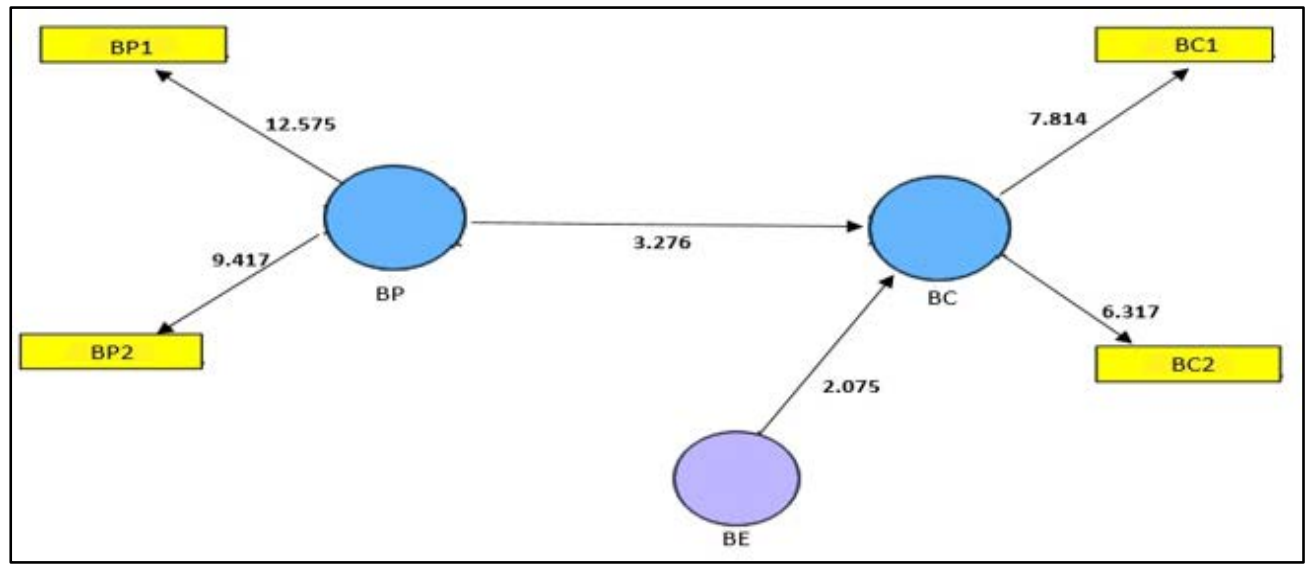

Figure 2: the final model of the study based on t values

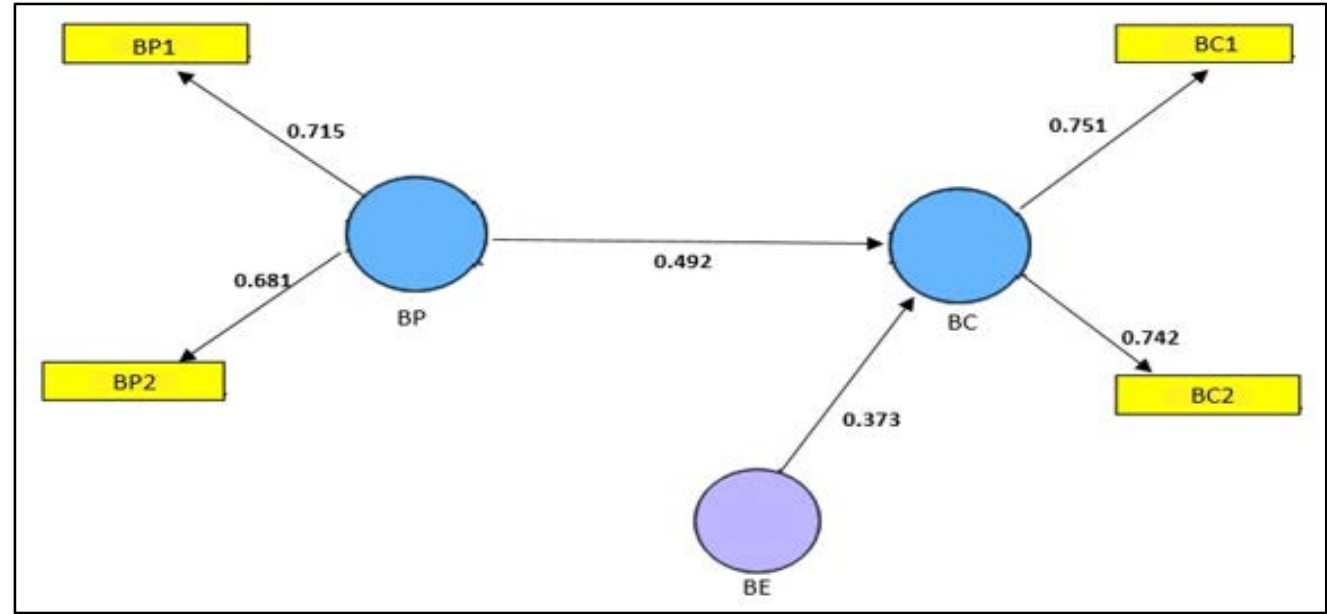

Figure 3: the final model of the study based on the coefficients and paths of load factors

\subsection{The second hypothesis of the study}

In order to evaluate the second hypothesis of the study, once more the main model of the study was performed without considering the adjusting role of brand ethics. The results thus gained are presented as the figures 4 and 5 below. According to the final model of the study based on t values, as the value of $t$ was found to be greater than 1.96 in the relation between brand passion and brand commitment, we can conclude that here also the relationship between these two variables is significant.

And regarding the final model of the study, and based on the coefficients and paths of load factors, as the value of load factor is 0.51 , we can conclude that the brand passion variable can predict the changes in brand commitment. Therefore, the second hypothesis of the study is also affirmed and brand passion can affect brand commitment even without the adjusting role of the brand ethics. 
DOI: 10.14807/ijmp.v11i7.1239

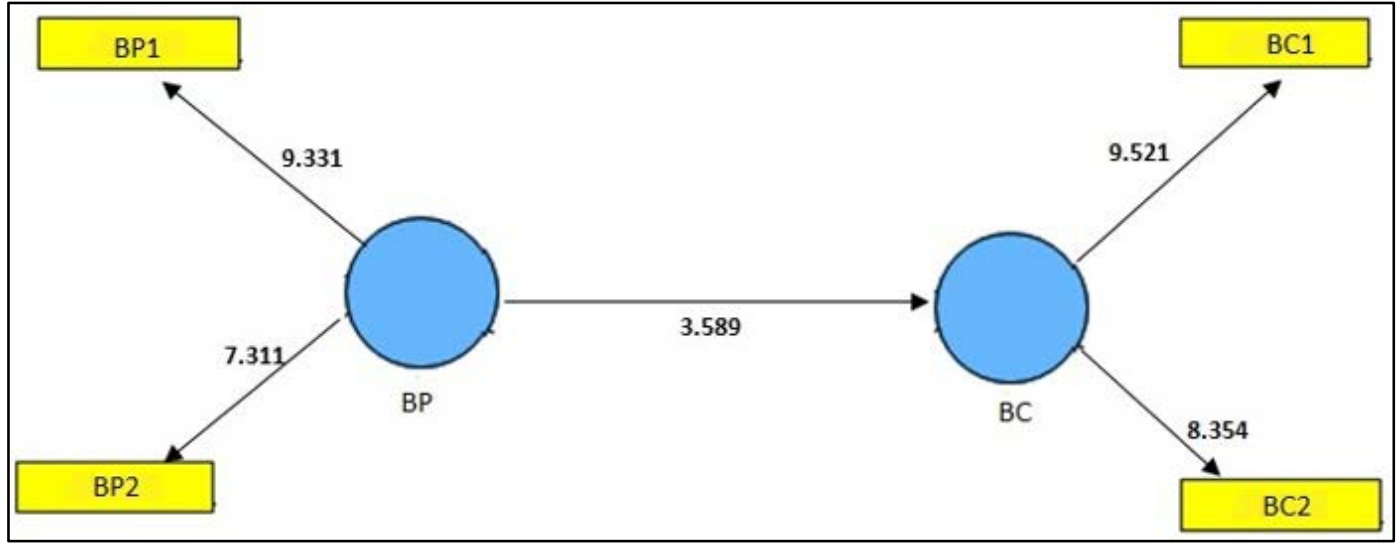

Figure 4: the final model of the study based on $t$ values without the adjusting role of brand ethics

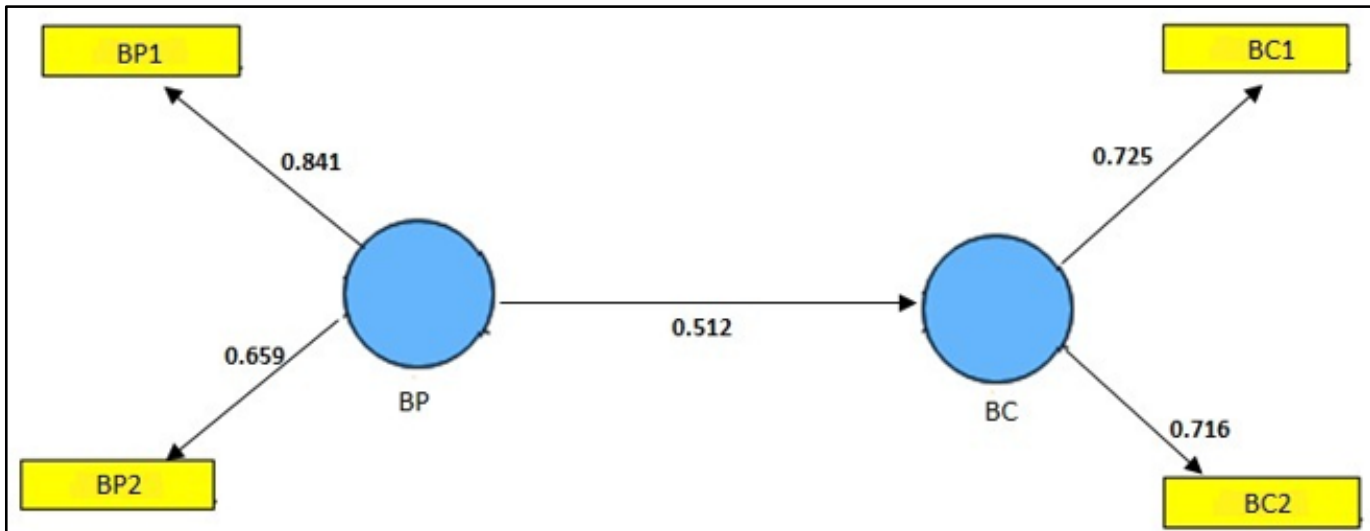

Figure 5: the final model of the study based on the coefficients and paths of load factors without the adjusting role of brand ethics

As we can see, the two hypotheses of the study are affirmed, and we can say that brand passion can affect brand commitment among the consumers of sanitary cleaners and detergents while brand ethics can adjust the effects.

\section{CONCLUSION}

Nowadays, morality is the missing aspect of the businesses of all kinds, while it is now certain that they can create and present a more powerful brand and affect the customers' emotional relationships with their brand through observing ethicality in its two main aspects and also the moral outcomes of their transactions as telling factors for the customers. The present research project aimed at studying the adjusting role of brand ethics on the effects of brand passion on brand commitment.

Results from testing the hypotheses showed that the relationship between the variables of brand passion and brand commitment is a significant one while the brand ethics has an adjusting role in such relationship. Therefore, it is recommended that the manufacturers of 
DOI: 10.14807/ijmp.v11i7.1239

sanitary cleaners help enhance their customers' commitment to their brands by observing moral issues in the production of their products and after presenting them to the market.

If the production of such goods are done based on suitable standards, and at the same time sufficient care be taken of the liability of economic organizations, such as environmental issues, human rights, and poor people, the customers would certainly be more committed to the products and the brand will find the pursuit of their aims along with the greater aims of society.

\section{REFERENCES}

ALBERT, N.; MERUNKA, D.; VALETTE-FLORENCE, P. (2010) Passion for the Brand and Consumer Brand Relationships, p. 1-9.

ALBERT, N.; MERUNKA, D.; VALETTE-FLORENCE, P. (2013) Brand passion: Antecedents and consequences. Journal of Business Research, v. 66, p. 904-909.

ALKILANI, K.; LING, K. C.; ABZAKH, A. A. (2012) The impact of experiential marketing and customer satisfaction on customer commitment in the world of social networks. Asian Social Science, v. 9, n. 1, p. 262- 270.

BARNETT, C.; CAFARO, P.; NEWHOLM, T. (2005) Philosophy and ethical consumption.

BECHWATI, N. N.; MORRIN, M. (2003) Outraged consumers: Getting even at the expense of getting a good deal. Journal of Consumer Psychology, v. 13, p. 440-453.

BRUNK, K. H. (2012) Un/ethical company and brand perceptions: Conceptualizing and operationalising consumer meanings. Journal of Business Ethics, v. 4, n. 111, p. 551-565.

CASTALDO, S.; PERRINI, F.; MISANI, N.; TENCATI, A. (2009) The Missing Link between Corporate Social Responsibility and Consumer Trust: The Case of Fair Trade Products. Journal of Business Ethics, v. 84, n. 1, p. 1-15.

EGAN-WYER, C.; LOUISE M.; SARA, A. P.; SVENSSON, P. (2014) The ethics of the brand, ephemera: theory \& politics in organization, v. 14, n. 1.

ERCIŞ, A.; UNAL, S.; CANDAN, F. B.; YILDIRIM, H. (2012) The effect of brand satisfaction, trust and brand commitment on loyalty and repurchase intentions. Procedia -

Social and Behavioral Sciences, v. 58, p. 1395-1404.

GOPAL D.; AGARWALB J.; NARESH K.; MALHOTRAC, G. V. (2018) Does brand experience translate into brand commitment?: A mediatedmoderation model of brand passion and perceived brand ethicality. Journal of Business Research, available at: https://doi.org/10.1016/j.jbusres.2018.05.026.

GROHMANN, B.; BODUR, H. O. (2015) Brand social responsibility: Conceptualization, measurement, and outcomes. Journal of Business Ethics, v. 131, n. 2, p. 375-399.

GUSTAFFSSON, A.; JOHNSON, M. J.; ROOS, I. (2006) The effects of customer satisfaction, relationship commitment dimensions, and triggers on customer retention [Electronic version]. Journal of Marketing, v. 4, n. 69, p. 210-218.

HEINRICH, D.; BAUER, H. H.; JOHANNES, C. M. (2009) Measuring Brand Love: Applying Sternberg's Triangular Theory of Love in Consumer-brand Relations, University of Mannheim. 
DOI: 10.14807/ijmp.v11i7.1239

JOHNSON, M. D.; MORGESON, F. P.; HEKMAN, D. R. (2012) Cognitive and affective identification: Exploring the links between different forms of social identification and personality with work attitudes and behavior. Journal of Organizational Behavior, 33, 1142-1167.

KEH, H. T.; PANG, J.; PENG, S. (2007) Understanding and measuring brand love. Advertising and Consumer Psychology, New Frontiers in Branding: Attitudes, Attachments, and Relationships. Santa Monica, CA.

LASSAR, W.; MITTAL, B.; SHARMA, A. (1995) Measuring customer-based brand equity. Journal of Consumer Marketing, v. 12, n. 4, p. 11-19.

MOORMAN, C.; ZALTMAN, G.; DESHPANDE, R. (1992) Relationship between providers and users of market research: The dynamics of trust within and between organization, Journal of Marketing Research, v. 29, n. 3, p. 314-329.

MORGAN R. M.; HUNT, S. D. (1994) The commitment-trust theory of relationship management, Journal of Marketing, v. 58, p. 20-38.

PALIHAWADANA, D.; OGHAZI, P.; LIU, Y. (2016) Effects of ethical ideologies and perceptions of CSR on consumer behavior. Journal of Business Research, v. 11, n. 69, p. 4964-4969.

PARK, C. W.; EISINGERICH, A. B.; PARK, J. W. (2013) Attachment-aversion (AA) model of customer-brand relationships. Journal of Consumer Psychology, v. 23, n. 2, p. 229-248.

RAUSCHNABEL, P. A.; AHUVIA, A. C. (2014) You're so lovable: Anthropomorphism and brand love. Journal of Brand Management, v. 21, n. 5, p. 372-395.

SINGH, J. J.; IGLESIAS, O.; BATISTA-FOGUET, J. M. (2012) Does having an ethical brand matter? The influence of consumer perceived ethicality on trust, affect and loyalty. Journal of Business Ethics, v. 111, n. 4, p. 541-549.

SWIMBERGHE, K. R.; ASTAKHOVA, M.; WOOLDRIDGE, B. R. (2014) A new dualistic approach to brand passion: Coordinatedand obsessive. Journal of Business Research, v. 67, n. 12, p. 2657-2665.

THOMSON, M.; MACINNIS, D. J.; PARK, C. W. (2005) The ties that bind: Measuring the strength of consumers' emotional attachments to brands. Journal of Consumer Psychology, v. 15, n. 1, p. 77-91. 